\title{
The Influence of Feeding Regimen on the Composition of the Fat Pads in the Bovine Digital Cushion
}

\author{
Martha Räber ${ }^{1,2 *}$, Vera Letter ${ }^{2,3}$, André Chassot ${ }^{4}$, Hans Geyer ${ }^{2}$, Martin R. L. Scheeder ${ }^{5}$ \\ ${ }^{1}$ Consulting and Health Service for Small Ruminants, Herzogenbuchsee, Switzerland \\ ${ }^{2}$ Institute of Veterinary Anatomy, University Zurich, Switzerland \\ ${ }^{3}$ Clinic Aarau West, Oberentfelden, Switzerland \\ ${ }^{4}$ Federal Research Station for Animal Production, ALP, Posieux, Switzerland \\ ${ }^{5}$ Institute of Animal Science, ETH Zurich, (Now) Applied Sciences, School of Agriculture, Forest and Food \\ Sciences, Zollikofen, University of Bern, Switzerland \\ Email: ${ }^{*}$ martha.raeber@caprovis.ch
}

Received 22 July 2015; accepted 4 September 2015; published 7 September 2015

Copyright (C) 2015 by authors and Scientific Research Publishing Inc.

This work is licensed under the Creative Commons Attribution International License (CC BY). http://creativecommons.org/licenses/by/4.0/

(c) (7) Open Access

\section{Abstract}

The effect of an intensive/extensive feeding regimen on lipid content and fatty acid composition of the bovine digital cushion was investigated in 32 beef cattle of both genders, divided in 2 groups (16 per intensive/extensive feeding). The beef cattle were calves of different suckler cow husbandries. After the separation from their mothers at the age of 10 months, they were differently fed for 5 months. The animals were slaughtered at the age of $\mathbf{1 5}$ months with a mean body weight of $450 \mathrm{~kg}$. The macroscopic claw examination of all beef cattle was made at two defined claws at the beginning of the trial and after slaughter. For applicatory reasons, the fat pads of the claws could only be prepared after slaughter. Samples from fat pads at defined locations of the digital cushion were analysed for lipid content and fatty acid composition determination. Additionally, samples from the digital cushions and few samples of subcutaneous tissue of 9 dairy cows served as comparison. These slaughterhouse cows were mainly fed with hay and grass; further data however were not available. The digital fat pads and the subcutaneous fat of both groups showed obvious differences in the fat content and the fatty acid composition. The fat pads of the intensive fed animals contained fewer lipids and more omega-6-fatty acids. The extensive fed animals had distinctly more omega-3-fatty acids. In the subcutaneous fat of the intensive fed animals, more omega-6-fatty could be found and more omega-3-fatty acids in the extensive fed animals. These results indicate that the feeding can influence the lipid content and the fatty acid composition. The macroscopic hoof horn quality grade of the intensive fed group was better than the extensive fed group. The digital pads of the dairy cows contained more lipids, more monounsaturated fatty acids and less omega-6-fatty acids.

\footnotetext{
${ }^{*}$ Corresponding author.
}

How to cite this paper: Räber, M., Letter, V., Chassot, A., Geyer, H. and Scheeder, M.R.L. (2015) The Influence of Feeding Regimen on the Composition of the Fat Pads in the Bovine Digital Cushion. Agricultural Sciences, 6, 889-899. 


\section{Keywords}

\section{Suckler Cow Husbandry, Claws, Nutrition, Fatty Acids}

\section{Introduction}

No claw no cow-an old saying, but is still applicable. Worldwide research found out that about $60 \%$ of a herd become lame once a year [1]. The financial loss from claw diseases is huge and consists of obvious losses and hidden costs, and the animal welfare is highly affected by claw problems [2]-[4]. Different risk factors involved, such as claw conformation and trimming, cow comfort, management and nutrition have already been examined in a number of studies [1]-[5]. However, no solution for this crucial problem has been found yet.

The fat pads in the bovine digital cushion contain different amounts of lipids [6]-[11]. These pads have a shock-absorbing effect and may contribute to claw health in different manners. It is known that diet influences lipid composition in depot fat [12]. Therefore, one can speculate that if the fat pads in the digital cushion can also be influenced by diet, this can counteract certain claw diseases.

The aim of the present study was to investigate the influence of 2 different feeding regimens on lipids of the fat pads of the digital cushion in beef cattle and to compare the results with the effects on subcutaneous fat. Moreover, it is known that the pressure distribution under the claw strongly varies and that certain areas of the claw are more prone to lesions [13]. The trial therefore should also clarify if feeding regimen influences lipid composition in the various locations within the claw and/or the front and hind claws differently. The results should be compared with findings of digital pads and subcutaneous fat of dairy cows.

\section{Materials and Methods}

\subsection{Animals}

Two study groups included 32 cow-calves (8 Angus, 8 Eringer, 8 Limousin and $8 \mathrm{~F}_{2}$ [Limousin $\times$ (Limousin $\times$ Red Holstein)]) of both genders raised at the Federal Research Station for Animal Production (ALP in Posieux, Switzerland) and grazed on alpine or lowland pastures. The birth period was from November 11, 2004 to January 18,2005 . At the onset of the trial, the animals were ten to twelve months old.

\subsection{Housing and Feeding}

The Angus and Eringer calves were allocated to an extensive feeding regimen whereas the Limousin and $\mathrm{F}_{2}$ calves were allotted to a more intensive feeding regimen, according to the production types of these breeds (hereafter entitled "intensive" and "extensive" groups).

The animals were kept in straw bedded pens with a solid concrete feeding place and a concrete outdoor site. Both groups received roughage ad libitum. Additionally, the intensive group was offered 3 - $4.5 \mathrm{~kg}$ concentrate per head per day throughout the study. The extensive group received $0.5 \mathrm{~kg}$ concentrate per head per day up to week 13 when the rate was increased to $1.8-2.5 \mathrm{~kg} / \mathrm{d}$ (see Table 1 for diet composition). After having reached fat class 3 (according to the EUROP carcass classification grid) the animals were slaughtered at an average age of $13.6 \pm 0.91$ or $15.3 \pm 1.07$ months for the intensive and the extensive group, respectively. None of them showed signs of lameness at any time of the trial.

With respect to our first results [6] and for a comparison with these young beef cattle, 9 slaughtered dairy cows were included in this investigation [14]. These cows mainly received hay, grass and a small amount of concentrate. More information to the feeding regimen of these cows was not available.

\subsection{Examination of the Claws}

The claws of the beef cattle were scored at the beginning of the barn feeding and post mortem, the cows' claws only post mortem. For the left front and the right hind foot, claw alterations were typified and scored using a scale from 0 to 3 with quarterly segments: 0 - 0.25 (unaltered), 0.5 - 1.25 (mild), 1.5 - 2.25 (moderate), 2.5 - 3 
Table 1. Nutrient content of the feedstuffs ${ }^{1}$ (mean values).

\begin{tabular}{|c|c|c|c|c|c|c|c|}
\hline \multirow[b]{2}{*}{ Feedstuffs } & \multirow{2}{*}{$\begin{array}{c}\text { Dry } \\
\text { matter } \\
(\%)\end{array}$} & \multicolumn{6}{|c|}{ Content of 1 kg dry matter ${ }^{2}$} \\
\hline & & Ash (g) & $\begin{array}{l}\text { Crude protein } \\
\text { (g) }\end{array}$ & $\begin{array}{l}\text { Crude fibre } \\
\text { (g) }\end{array}$ & $\begin{array}{c}\text { Net } \\
\text { energy }(\mathrm{MJ} \mathrm{NE} \text { ) }\end{array}$ & PDE (g) & PDIN (g) \\
\hline Maize silage & 34.0 & 33.2 & 76.1 & 190.6 & 6.8 & 72.6 & 46.8 \\
\hline Grass silage & 33.3 & 147.3 & 172.0 & 223.2 & 6.2 & 77.1 & 104.9 \\
\hline Hay & 88.8 & 92.4 & 125.9 & 276.3 & 5.8 & 91.1 & 83.0 \\
\hline Roughage int. group ${ }^{3}$ & 33.6 & 61.7 & 100.1 & 198.7 & 6.7 & 73.7 & 61.3 \\
\hline Roughage ext. group ${ }^{4}$ & 40.6 & 133.6 & 160.5 & 236.4 & 6.1 & 80.6 & 99.4 \\
\hline Concentrate of int. group ${ }^{5}$ & 87.1 & 75.6 & 229.6 & 31.0 & 7.4 & 135.9 & 153.9 \\
\hline Concentrate of ext. group ${ }^{6}$ & 87.8 & 93.1 & 169.2 & 101.7 & 6.8 & 94.6 & 110.6 \\
\hline Concentrate of ext. group ${ }^{7}$ & 87.4 & 31.7 & 117.8 & 42.8 & 8.9 & 93.7 & 72.1 \\
\hline
\end{tabular}

int.: intensive; ext.: extensive. ${ }^{1}$ Frequency of the analyses: dry matter (DM) of the forages twice a week; ash, crude protein and crude fibre twice a month. ${ }^{2} \mathrm{NE}$ : net energy for growth, PDIE: protein supplied when energy is limited in the rumen, PDIN: protein supplied when nitrogen is limited in the rumen. PDIE and PDIN of the concentrates are calculated using tabular values of their components ${ }^{\mathrm{b}}$ (ALP, 2008). ${ }^{3}$ Roughage intensive group: $3: 1$ mixture of maize and grass silage in the DM. ${ }^{4}$ Roughage extensive group: 3:1 mixture of hay and grass silage in the DM. ${ }^{5}$ Composition: maize grains $(32.9 \%)$, wheat $(28.2 \%)$, soybean meal $(32.9 \%)$, sodium bicarbonate $(4.0 \%)$, sodium chloride $(0.4 \%)$, trace element and vitamin premix $(1.6 \%)$. ${ }^{6}$ Composition: wheat bran (93.7\%), crystalline fat Alikon ${ }^{\circledR}(4.0 \%)$, sodium chloride (2.3\%). Feeding during 12 weeks following the adaptation period. ${ }^{7}$ Composition: barley (95.3\%), crystalline fat Alikon ${ }^{\circledR}(4.0 \%)$, sodium chloride $(0.6 \%)$, trace element and vitamin premix $(0.1 \%)$. Fed from the $13^{\text {th }}$ week of investigation until slaughter. ${ }^{\mathrm{b}}$ ALP: Agroscope Liebefeld Posieux, Posieux, Switzerland. Nutritionel requirements, 2008.

(severe) changes.

\subsection{Lipid Content and Fatty Acid Analysis}

After slaughter all claws were stored at $-20^{\circ} \mathrm{C}$ until thawed and heated for one hour in $60^{\circ} \mathrm{C}$ to $65^{\circ} \mathrm{C}$ warm water. The horn shoe was removed and the soft tissue of the sole and heel of the lateral claws was separated using a standardised cut [15]. A colour scale served as referee to define evenly the yellow tones of the fat pads [14]. Pad samples of the digital cushion were collected from three defined locations (B, D, F; Figure 1), corresponding roughly to the zones proposed by [13] describing the typical lesion areas in the horn shoe. Pad B was estimated as medium loaded, $\mathrm{D}$ as low and $\mathrm{F}$ as highly loaded.

Subcutaneous fat samples were taken from the base of the tail of all beef cattle and 4 of 9 dairy cows. The lipids were extracted from pads and subcutaneous fat and analysed by gas chromatography as described earlier [6].

\subsection{The Following Abbreviations Were Used for the Different Fatty Acids}

SFA: saturated fatty acids

MUFA: monounsaturated fatty acids

PUFA: polyunsaturated fatty acids

AA: arachidonic acids

LA: linoleic acids

$\alpha$-LA: $\alpha$-linolenic acids

n-3-FA: omega-3-fatty acids

n-6-FA: omega-6-fatty acids

\subsection{Data and Statistical Analysis}

The data were analysed by use of a statistical software program (StatView Version 5.1 SAS Inst. Inc., NC, USA). The obtained results were compared between feeding groups, front and hind claws, location (B, D, F) as well as category (cow, beef) using Mann-Whitney-U or Kruskal-Wallis Test. If the dependent variable was estimated as normal distribution by means of the Wilk-Shapiro Test, the unpaired t-Test was used for two-level factorial 


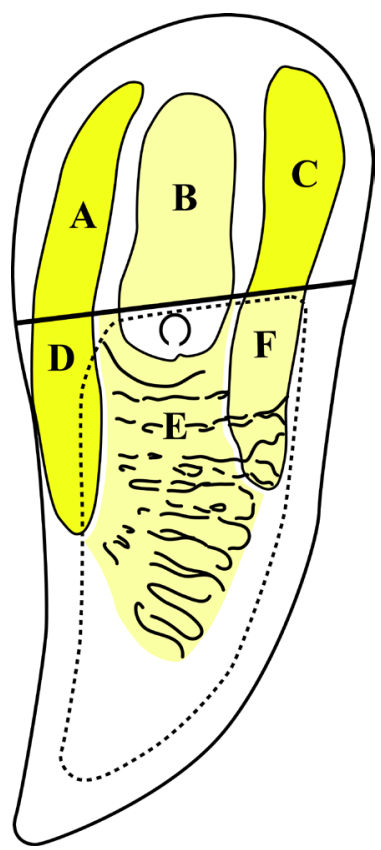

Figure 1. A schematic drawing of the fat pads after having cut off the corium and the subcutis of the sole and heel segment from the distal phalanx (proximal view onto the cut surface). A, D: axial pad; B: middle pad; C, F: abaxial pad; E: transversal pad. Locations of the investigated specimens with the estimated load: D: low; B: middle; F: high.

analysis. If the normally distributed dependent variable was a repeated measure by means on the same animal, the paired t-Test was used for two-level factorial analysis. According to the two-level analysis, analysis of variance (ANOVA) with Bonferroni correction was applied to multi-level factor or factors. In all tests, the level of significance was set at $\mathrm{P}<0.05$.

The trial was approved by the animal welfare department of the cantonal government authority of Fribourg (Approval No. 69/2004) Switzerland.

\section{Results}

\subsection{Macroscopic Findings}

Claw quality clearly declined between the first examination and slaughter in all beef cattle. The most severe alterations were heel horn erosions at the transition of the apical to the middle part of the bulb and in the interdigital space were the most found alterations. At slaughter, both examined claws of the intensive group got a better grade than the extensive group. The average score of the extensive/intensive group was $0.31 / 0.39$ respectively at the onset and 0.97/0.52 at the end of the trial. Moreover, front claws were worse than hind claws but subcutis and corium were unchanged. All alterations were in the category "mild changes" though. None of the beef cattle showed signs of lameness during the trial.

\subsection{The Three Fat Pads of the Digital Cushion}

In general, the fat pads were clearly visible and no pathological changes; only the transverse connections between the axial and the abaxial pad and the anterior part of the abaxial pad (=pad F) were faintly designed. Comparing the pads of the different beef breeds, those of the Eringer were very distinctly built, but the cows' pads were even better developed and easy to identify: they showed an intense yellow colour and the consistency of the pads of the cows was, contrary to the younger beef cattle, greasier, oilier and softer.

\subsection{Lipid Content in the Fat Pads}

The samples of the extensive group had higher lipid content than the intensive group (Table 2). The cows 
Table 2. Lipid content and lipid composition of the fat pads of beef cattle and dairy cows (mean values).

\begin{tabular}{ccccccc}
\hline Fat pads & $\begin{array}{c}\text { Beef } \\
\text { extensive } \\
\mathrm{n}=16\end{array}$ & $\begin{array}{c}\text { Beef } \\
\text { intensive } \\
\mathrm{n}=16\end{array}$ & $\begin{array}{c}\text { Beef } \\
\text { total } \\
\mathrm{n}=32\end{array}$ & $\begin{array}{c}\text { Cows } \\
\text { total } \\
\mathrm{n}=9\end{array}$ & $\begin{array}{c}\text { P group } \\
\text { beef/cows }\end{array}$ & $\begin{array}{c}\text { P group } \\
\text { ext/int }\end{array}$ \\
\hline $\begin{array}{c}\text { Lipid content } \\
\text { Lipid comp. }^{3}\end{array}$ & 17.1 & 8.77 & 12.9 & 28.2 & $<0.0001$ & $<0.0001$ \\
SFA & 18.1 & 20.1 & 19.1 & 13.8 & $<0.0001$ & 0.0006 \\
MUFA & 75.7 & 73.4 & 74.5 & 80.2 & $<0.0001$ & 0.0077 \\
PUFA & 2.63 & 3.71 & 3.18 & 2.58 & 0.2021 & 0.0223 \\
LA & 1.31 & 2.03 & 0.35 & 1.42 & 0.0655 & $<0.001$ \\
AA & 0.24 & 0.56 & 0.40 & 0.17 & 0.0230 & 0.0131 \\
$\alpha$-LA & 0.44 & 0.26 & 0.36 & 0.40 & 0.2519 & 0.0025 \\
n-3-FA & 0.92 & 0.81 & 0.86 & 0.83 & 0.8707 & 0.4887 \\
n-6-FA & 1.76 & 2.90 & 2.31 & 1.71 & 0.1470 & 0.002 \\
\hline
\end{tabular}

${ }^{1}$ including all investigated fat pads (B, D and F) in front and hind claws. Beef cattle total: 2 groups ( 6 samples $\times 16$ animals), cow total: 6 samples $\times 9$ animals. ${ }^{2}$ Lipid content: sum of fatty acids calculated as triacylglycerol in g/100g fresh tissue of the pads. ${ }^{3}$ Lipid composition: g/100g fatty acid methylesters. SFA, saturated fatty acids; MUFA, monounsaturated fatty acids; PUFA, polyunsaturated fatty acids; LA, linoleic acid; AA, arachidonic acid; $\alpha$-LA, $\alpha$-linolenic acid; n-3-FA, omega-3 fatty acids; n-6-FA, omega-6 fatty acids.

showed the highest lipid content in the pads (28.2\%). The pads of the front claws generally contained more lipids than the hind claw pads. The lipid content in the pads at the three locations within the digital cushion differed significantly as well (Table 4).

\subsection{Lipid Composition of the Fat Pads}

All the digital pads showed a high proportion of MUFA (monounsaturated fatty acids) (approximately $70 \%$ $80 \%$; Table 2). The extensive group had more MUFA than the intensive group and the cows had significantly more MUFA than the beef cattle. The higher proportion of MUFA was at the expense of SFA and PUFA as well. The n-6-FA, namely LA and AA, made up the highest proportion of PUFA in the intensive group, whereas the $\alpha$-LA of the n-3-FA were more presented in the samples of the extensive group. Together with the lipid content, which is double, the amount of n-3-FA was significantly higher in the pads of the extensive group compared to the intensive group. The means of the n-3-FA per $1000 \mathrm{mg}$ pad tissue was $1.52 \mathrm{mg}$ in the extensive group, 0.65 $\mathrm{mg}$ in the intensive group and $0.23 \mathrm{mg}$ in the cows. The n-3-FA differed significantly between the 3 groups in all statistical tests. Moreover, the cows showed a lower proportion of AA than the beef cattle (Table 2).

\subsection{Relationship between Load, Location and Lipids}

According to the results of [13] and the gait studies of [16]-[18], the pads at the defined locations (B, D and F) are subjected to different load (Figure 1). The paired t-Test showed that pads B and D in the same claw had a higher amount of fatty acids than pad F, which carries the highest load (Table 4). The low loaded area (D) contained the highest amount of total fatty acids (i.e. lipid content). Also in pad F, the highest loaded area, could be found a higher proportion of PUFA, mainly AA and LA than in the other locations (Table 4). The intensive group had the highest proportion of PUFA in pad F. However, as the intensive group had the lowest content of total fatty acids, the PUFA content per $1000 \mathrm{mg}$ pad tissue was higher in the extensive group (2.38 mg PUFA in front and $1.41 \mathrm{mg}$ in rear claws) than in the intensive group (0.88 mg PUFA in front and $0.50 \mathrm{mg}$ in rear claws). In addition there was a relationship between the degree of pressure load on the pads according to [13] and the relative amount of AA. Pad F, as a very highly loaded pad, had the highest portion of AA in all animals (Table 4).

\section{Subcutaneous Fat}

\subsection{Lipid Content}

In the subcutaneous fat the lipid content was much higher than in the pads (Table 4). The cows showed lower lipid content in subcutaneous fat than the beef cattle (Table 3). 
Table 3. Lipid content and lipid composition of the subcutaneous fat of beef cattle and dairy cows (mean values).

\begin{tabular}{ccccccc}
\hline Subcutaneous fat & $\begin{array}{c}\text { Beef } \\
\text { extensive } \\
\mathrm{n}=16\end{array}$ & $\begin{array}{c}\text { Beef } \\
\text { intensive } \\
\mathrm{n}=16\end{array}$ & $\begin{array}{c}\text { Beef } \\
\text { total } \\
\mathrm{n}=32\end{array}$ & $\begin{array}{c}\text { Cows } \\
\text { total } \\
\mathrm{n}=4\end{array}$ & $\begin{array}{c}\text { P group } \\
\text { beef/cows }\end{array}$ & $\begin{array}{c}\text { P group } \\
\text { ext/int }\end{array}$ \\
\hline $\begin{array}{c}\text { Lipid content } \\
\text { Lipid comp** }\end{array}$ & 78.3 & 73.5 & 76.0 & 65.9 & 0.02 & 0.0753 \\
SFA & 45.3 & 45.6 & 45.4 & 38.6 & 0.0103 & 0.7418 \\
MUFA & 47.1 & 47.3 & 47.1 & 53.6 & $<0.0001$ & 0.4459 \\
PUFA & 2.36 & 2.63 & 2.49 & 2.10 & 0.0297 & 0.0027 \\
LA & 0.81 & 0.40 & 0.62 & 0.58 & 0.8955 & $<0.0001$ \\
AA & 0.03 & 0.04 & 0.03 & 0.04 & 0.7233 & $<0.0001$ \\
$\alpha$-LA & 1.29 & 1.96 & 1.60 & 1.25 & 0.0867 & $<0.0001$ \\
n-3-FA & 0.95 & 0.48 & 0.73 & 0.69 & 0.8955 & $<0.0001$ \\
n-6-FA & 1.41 & 2.15 & 1.76 & 1.40 & 0.2172 & $<0.0001$ \\
\hline
\end{tabular}

Beef: beef cattle. " Lipid content: sum of fatty acids calculated as triacylglycerol in g/100g fresh tissue of the pads. ${ }^{* *}$ Lipid composition: g/100g fatty acid methylesters SFA, saturated fatty acids; MUFA, monounsaturated fatty acids; PUFA, polyunsaturated fatty acids; LA, linoleic acid; AA, arachidonic acid; $\alpha$-LA, $\alpha$-linolenic acid; n-3-FA, n-3-(omega-3) fatty acids; n-6-FA, n-6-(omega-6) fatty acids.

\subsection{Lipid Composition}

The proportion of MUFA and SFA were approximately 45\% in all beef cattle, while in cows the SFA portion was lower. The extensive group had more n-3-FA than the intensive group and the cows as well. The portion of n-6-FA compared to the n-3-FA was higher in pads than in subcutaneous fat. Accordingly the AA portion was higher as well (Table 2 and Table 3).

\section{Discussion}

\subsection{Macroscopic Examination of the Claws}

In this study the claws of the intensive group had better claw horn quality and showed less heel horn erosions than the extensive group although the housing of all animals was the same. The extensive group as well had no severe heel erosions and the dermis was not irritated in both groups. The average grade of the intense group was 0.52 and 0.97 in the extensive group. Both scores still belong to the category "mild changes".

At slaughter, the intensive group was 1.5 - 2 months younger than the extensive group and thus these animals were not so long exposed to the environment as the extensive ones. Besides, the poorer hoof horn quality of the extensive group could be partly caused by feeding composition, e.g. lower content in proteins, minerals or vitamins (Table 1).

\subsection{Different Lipid Amount and Lipid Composition in the Digital Fat Pads}

There was a remarkable higher amount of lipids and differences in composition in the pads of the extensive group within the short experimental time of 3 - 4 months to see [17] (Table 2). The differences in lipid content and lipid composition of the pads between the extensive and the intensive group can mainly be attributed to feeding effects, because no significant differences between the 2 breeds within the groups were seen. The excessive lipid accretion of the carcasses of the extensive group-mainly the Angus-can be considered as a genetic effect [19]. The differences in fatty acid composition of depot fat and claw fat pads may also be influenced by age, weight and genetic factors as well as by nutrition [20].

The cows' fat pads showed more than the double lipid amount than those of the beef cattle (Table 2), which can most probably be explained by the big difference in age. It was noticed, that the pads of cows up to the $4^{\text {th }}$ lactation have higher lipid content than 1 - 3 year old heifers [5]. Thereafter the lipid content decreases and lipid is replaced by connective tissue [6] [10]. The risk of having diagnosed claw lesions was significantly higher in cows with thinner digital cushions [21]. Reference [6] suggests that during the first lactation compositional 
changes in the pads take place to ensure an optimal shock-absorbing effect for the increasing load. Moreover, reference [22] found out that the laxity of the connective tissue of the supporting apparatus of the third phalanx increases due to calving and together with external factors, as concrete floor, is able to trigger claw lesions.

\subsection{Differences in the Fatty Acid Composition}

Several studies show that the composition of the fatty acids in adipose tissue can be modified by feeding measures [12] [23] [24]. In ruminants the depot fat is influenced by the fatty acids in the feed, stored as such or after modification during ruminal biohydrogenation [12] as well as by the extent of fatty acid de novo synthesis. The differences in fatty acid composition between the extensive and intensive groups may therefore partly be explained by the feeding regimen and partly by the differences in fat accretion attributable to breed.

The digital pads showed a remarkably higher proportion of MUFA than the adipose tissue. The high amount of MUFA and PUFA (Tables 2-4) is responsible for the very soft fat in the pads [6]. The liquid-like consistency of the pads can serve as a hydraulic system, which is very well adapted to load bearing of the claw. The high proportion of MUFA could also be due to lower temperatures in the claws than in other body regions. It was shown in pigs that the proportion of MUFA and presumably the activity of stearoyl-CoA-desaturase in subcutaneous fat of pigs depend on the ambient temperatures, being higher with lower temperatures [25]. It can be shown by thermography that the distal parts of healthy extremities have lower temperatures than the region of the trunk. This leads to claw lipids with a low melting point, which may have a cushioning effect like liquids. It is questionable though that the temperature differences are the only reason for the high proportion of MUFA in the pads.

The PUFA in the pads and the subcutaneous fat showed elevated n-6-FA in the intensive group, whereas the n-3-FA was higher in the extensive group. This fact can be explained by the different feeding regimens, which obviously affected the lipid composition of the claw pads even after a rather short experimental period.

$\alpha$-LA and LA are precursors of long-chain-PUFA, such as AA. Although the samples of the intensive group contained a higher proportion of n-6-FA, the absolute amounts of LA and AA were higher in the extensive group due to the higher lipid content in the pads and in the subcutaneous fat. Comparing the absolute values of AA with the claw condition of the beef we noticed that better heel horn conditions coincided with a lower AA content.

We know that AA is the most important precursor of eicosanoids, which modulate important physiological functions of different body systems and AA serves as an inflammatory mediator as well. It could be possible that AA up to a certain threshold or an optimal n-3/n-6-FA-ratio have a positive effect on the pads. A low AA content could, however, also indicate consumption of AA due to inflammation caused e.g. by squeezing. Regarding the good claw condition of the intensive group, it could be hypothesized that the AA influences the synthesis of the intercellular glue (membrane coating material) of the claw horn, which is very important for the cohesion of the horn cells.

In accordance to the results of [6], the pads of the cows had less AA than those of the beef cattle. This reduced proportion was explained by a potentially elevated consumption of AA for prostaglandin production due to chronic inflammation induced by excess load pressure.

In this study a relationship between the load pressure and the amount of AA could be demonstrated. All samples of pad F, mainly of the hind claws, had the highest proportion of AA; however, this was also correlated with lower lipid content. The intensive group had nearly twice as much AA as the extensive group. We conclude that the elevated proportion of AA is partly a feeding effect. It could also be speculated that the increased portion is caused in part by an augmented load pressure on the claws of these animals, as they were on average 40 kg heavier than the extensive animals at slaughter.

This study indicates that feeding regimen can change the lipid composition of the digital pads within a rather short time, which is proved as well in the study of [7]. These authors found that there is a threshold amount to incorporate fatty acids in the fat pads of the digital cushion. In accordance with other investigations, age and body weight (i.e. load) should be considered as further influencing factors, although, diet seems to have the highest impact on fatty acid composition of the fat pads (see also [20]). It remains a matter of conjecture if the fatty acid composition might be a critical factor or indicator for prevention of claw damage and claw inflammation. It would be interesting to elucidate the extent that dietary influence can contribute to the prevention of claw lesions and thus the well being of cattle. 
Table 4. (a)-(c) Lipid composition at the different locations B, D and F in the fat pads of front and hind claws and in the subcutaneous fat of all three groups $(1$ - 3) (means and standard deviation, s).

(a)

\begin{tabular}{|c|c|c|c|c|c|c|c|}
\hline Ext. group $/ \mathrm{n}=16$ & front B & front D & front $\mathrm{F}$ & hind B & hind D & hind $\mathrm{F}$ & sc fat \\
\hline Lipid content & 22.5 & 27.6 & 6.59 & 17.6 & 23.1 & 2.22 & 78.3 \\
\hline s & 9.74 & 8.72 & 12.12 & 8.7 & 9.49 & 3.79 & 3.99 \\
\hline SFA & 19.6 & 17.8 & $16.4^{\mathrm{i}, \mathrm{c}}$ & 19.6 & $17.8^{\mathrm{c}}$ & 16.9 & $45.3^{c}$ \\
\hline $\mathrm{s}$ & 1.76 & 1.78 & 1.908 & 1.449 & 1.154 & 2.521 & 2.606 \\
\hline MUFA & 75.1 & 76.1 & $76.8^{i}$ & $75.4^{\mathrm{i}}$ & $76.5^{c}$ & $73.8^{i}$ & 47.1 \\
\hline $\mathrm{s}$ & 1.63 & 1.90 & 1.89 & 1.10 & 1.32 & 6.51 & 2.82 \\
\hline PUFA & $1.62^{\mathrm{c}}$ & 1.77 & $3.61^{\mathrm{i}, \mathrm{c}}$ & $1.57^{\mathrm{i}}$ & 1.70 & 6.37 & 2.36 \\
\hline s & 0.20 & 0.29 & 1.64 & 0.23 & 0.23 & 4.67 & 0.22 \\
\hline LA & $0.81^{c}$ & 0.90 & $1.80^{\mathrm{i}, \mathrm{c}}$ & $0.78^{\mathrm{i}, \mathrm{c}}$ & 0.87 & 3.18 & 1.29 \\
\hline s & 0.11 & 0.144 & 0.8 & 0.11 & 0.11 & 2.22 & 0.14 \\
\hline AA & 0.07 & $0.057^{i}$ & $0.364^{\mathrm{i}, \mathrm{c}}$ & $0.073^{i}$ & $0.062^{i}$ & 0.994 & $0.027^{i}$ \\
\hline s & 0.026 & 0.011 & 0.266 & 0.02 & 0.014 & 1.067 & 0.005 \\
\hline$\alpha$-LA & $0.36^{\mathrm{c}}$ & 0.42 & $0.54^{\mathrm{c}}$ & 0.34 & 0.39 & 0.69 & $0.81^{\mathrm{c}}$ \\
\hline $\mathrm{s}$ & 0.057 & 0.09 & 0.20 & 0.06 & 0.07 & 0.28 & 0.07 \\
\hline n-3 total & $0.66^{c}$ & 0.73 & $1.19^{\mathrm{i}, \mathrm{c}}$ & $0.63^{i}$ & 0.69 & $1.79^{c}$ & $0.95^{\mathrm{c}}$ \\
\hline $\mathrm{s}$ & 0.10 & 0.15 & 0.46 & 0.10 & 0.12 & 1.11 & 0.09 \\
\hline n-6 total & $0.97^{c}$ & 1.04 & $2.42^{\mathrm{i}, \mathrm{c}}$ & $0.94^{\mathrm{i}, \mathrm{c}}$ & 1.01 & 4.57 & $1.41^{\mathrm{c}}$ \\
\hline s & 0.13 & 0.16 & 1.18 & 0.14 & 0.13 & 3.60 & 0.15 \\
\hline
\end{tabular}

(b)

\begin{tabular}{|c|c|c|c|c|c|c|c|}
\hline Int. group $/ \mathrm{n}=16$ & front B & front D & front $\mathrm{F}$ & hind $\mathrm{B}$ & hind D & hind $\mathrm{F}$ & sc fat \\
\hline Lipid content & 14.8 & 15.1 & 1.06 & 5.38 & 12.1 & 0.65 & 73.5 \\
\hline $\mathrm{s}$ & 11.6 & 6.13 & 1.11 & 5.17 & 4.95 & 0.22 & 9.52 \\
\hline SFA & 20.7 & 19.2 & $21.4^{\mathrm{e}, \mathrm{c}}$ & 19.4 & $20.1^{c}$ & 19.6 & $45.6^{c}$ \\
\hline $\mathrm{s}$ & 1.525 & 1.295 & 4.673 & 1.562 & 1.296 & 2.899 & 2.61 \\
\hline MUFA & 74.8 & 75.6 & $67.2^{\mathrm{e}, \mathrm{c}}$ & $75.4^{\mathrm{e}}$ & 75.2 & $70.3^{e}$ & 47.8 \\
\hline $\mathrm{s}$ & 1.36 & 1.49 & 8.46 & 1.92 & 1.35 & 5.63 & 2.58 \\
\hline PUFA & 1.61 & 1.65 & $8.38^{\mathrm{e}, \mathrm{c}}$ & $2.77^{\mathrm{e}}$ & 1.57 & 7.74 & 2.63 \\
\hline $\mathrm{s}$ & 0.29 & 0.21 & 4.40 & 1.36 & 0.25 & 3.27 & 0.23 \\
\hline LA & $0.92^{\mathrm{c}}$ & $0.97^{\mathrm{c}}$ & $4.36^{\mathrm{e}, \mathrm{c}}$ & $1.57^{\mathrm{e}, \mathrm{c}}$ & 0.94 & 4.46 & 1.96 \\
\hline $\mathrm{s}$ & 0.15 & 0.11 & 0.20 & 0.62 & 0.14 & 1.40 & 0.20 \\
\hline AA & $0.095^{c}$ & $0.076^{e, c}$ & $1.497^{e, c}$ & $0.36^{e}$ & $0.104^{\mathrm{e}, \mathrm{c}}$ & 1.699 & 0.043 \\
\hline $\mathrm{s}$ & 0.04 & 0.024 & 1.126 & 0.347 & 0.054 & 1.05 & 0.007 \\
\hline$\alpha$-LA & 0.23 & 0.28 & 0.34 & 0.22 & 0.23 & $0.26^{e, c}$ & $0.40^{c}$ \\
\hline $\mathrm{s}$ & 0.08 & 0.07 & 0.12 & 0.10 & 0.09 & 0.08 & 0.08 \\
\hline n-3 total & 0.48 & 0.50 & $1.70^{e, c}$ & $0.64^{e}$ & 0.43 & $1.19^{c}$ & $0.48^{\mathrm{c}}$ \\
\hline $\mathrm{s}$ & 0.13 & 0.10 & 1.70 & 0.35 & 0.11 & 0.71 & 0.09 \\
\hline n-6 total & 1.13 & 1.15 & $6.68^{\mathrm{e}, \mathrm{c}}$ & $2.12^{\mathrm{e}, \mathrm{c}}$ & 1.14 & 6.67 & $2.14^{\mathrm{c}}$ \\
\hline $\mathrm{s}$ & 0.19 & 0.13 & 3.14 & 1.03 & 0.20 & 2.65 & 0.22 \\
\hline
\end{tabular}

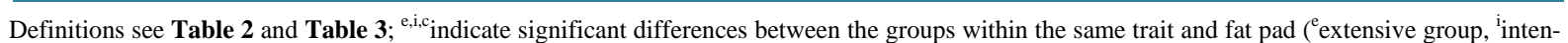
sive group, ${ }^{\mathrm{C}}$ cows) $\mathrm{P}<0.05$. 
(c)

\begin{tabular}{|c|c|c|c|c|c|c|c|}
\hline Cows $/ n=9$ & Front B & Front D & front $\mathrm{F}$ & hind B & hind D & hind $\mathrm{F}$ & $\begin{array}{c}\text { sc fat } \\
(\mathrm{n}=4)\end{array}$ \\
\hline Lipid content & 35.0 & 49.2 & 15.0 & 22.0 & 44.7 & 3.58 & 65.9 \\
\hline $\mathrm{s}$ & 17.2 & 8.8 & 8.9 & 15.6 & 15.70 & 3.3 & 10.6 \\
\hline SFA & 14.5 & 14.4 & $10.9^{\mathrm{e}, \mathrm{i}}$ & 14.8 & $15.7^{\mathrm{e}, \mathrm{i}}$ & 12.2 & $38.6^{\mathrm{e}, \mathrm{i}}$ \\
\hline $\mathrm{s}$ & 1.85 & 2.00 & 1.46 & 2.24 & 2.96 & 3.67 & 6.35 \\
\hline MUFA & 79.6 & 79.5 & $83.8^{\mathrm{i}}$ & 79.6 & $79.1^{\mathrm{e}}$ & $79.6^{c}$ & 53.6 \\
\hline $\mathrm{s}$ & 1.69 & 2.48 & 1.17 & 1.89 & 2.53 & 5.82 & 5.59 \\
\hline PUFA & $2.18^{\mathrm{e}}$ & 2.05 & $2.31^{e, i}$ & 2.19 & 1.81 & 4.94 & 1.73 \\
\hline s & 0.49 & 0.35 & 0.28 & 0.39 & 0.32 & 2.46 & 0.83 \\
\hline LA & $1.18^{\mathrm{e}, \mathrm{i}}$ & $1.14^{\mathrm{i}}$ & $1.30^{\mathrm{e}, \mathrm{i}}$ & $1.19^{\mathrm{e}, \mathrm{i}}$ & 1.01 & 1.71 & 1.25 \\
\hline $\mathrm{s}$ & 0.28 & 0.22 & 0.24 & 0.26 & 0.19 & 1.34 & 0.26 \\
\hline AA & $0.081^{i}$ & 0.068 & $0.107^{e, i}$ & 0.092 & $0.064^{i}$ & 0.582 & $0.036^{\mathrm{e}}$ \\
\hline $\mathrm{s}$ & 0.016 & 0.012 & 0.047 & 0.025 & 0.011 & 0.694 & 0.015 \\
\hline$\alpha$-LA & $0.39^{\mathrm{e}}$ & 0.38 & $0.34^{\mathrm{e}}$ & 0.36 & 0.31 & 0.62 & $0.58^{\mathrm{e}}$ \\
\hline $\mathrm{s}$ & 0.12 & 0.12 & 0.08 & 0.10 & 0.08 & 0.23 & 0.35 \\
\hline n-3 total & $0.77^{\mathrm{e}}$ & 0.71 & $0.76^{\mathrm{e}, \mathrm{i}}$ & 0.76 & 0.62 & $1.33^{\mathrm{e}, \mathrm{i}}$ & $0.69^{\mathrm{e}, \mathrm{i}}$ \\
\hline s & 0.20 & 0.16 & 0.14 & 0.20 & 0.17 & 0.33 & 0.41 \\
\hline n-6 total & $1.4^{\mathrm{e}}$ & 1.34 & $1.55^{\mathrm{e}, \mathrm{i}}$ & $1.44^{\mathrm{e}, \mathrm{i}}$ & 1.20 & 3.61 & $1.39^{\mathrm{e}, \mathrm{i}}$ \\
\hline $\mathrm{s}$ & 0.34 & 0.26 & 0.28 & 0.30 & 0.23 & 2.18 & 0.31 \\
\hline
\end{tabular}

\section{Conclusion}

In Conclusion, the two groups of beef cattle in the trial were kept in suckler cow husbandry with alpine farming up to the age to 10 months and a mean body weight of $300 \mathrm{~kg}$. Then, they were fed with different diets, which they received during wintertime. The intensive fed group got grass-corn-silage ad libitum and $3-4.5 \mathrm{~kg}$ concentrate (23\% crude protein). The extensive fed group received grass-silage and hay in a proportion of 3:1 ad libitum, and during 13 weeks $0.5 \mathrm{~kg}$ concentrate (17\% crude protein) and afterwards $2 \mathrm{~kg}$ concentrate (12\% crude protein). After a trial of 5 months, the beef cattle were slaughtered with a mean body weight of $450 \mathrm{~kg}$. The high amount of unsaturated fatty acids is responsible for the liquid like cushioning effect of the claw pads. The different composition of the pads at different claw locations seems to be in relation to different load in these locations. In a trial of 5 months, the differences in fatty acid composition of the claw pads between the two groups are remarkable. Information of the fatty acid composition at the beginning of the trial was not available, because the claw pads were obtained by a sophisticated anatomical dissection, which is only possible of slaughtered animals at the end of the trial. The higher omega-3-fatty acid content in the claw pads of the extensive fed group can give new ideas for anti-inflammatory prevention and improvement of claw health by nutritional factors.

\section{Acknowledgements}

The authors thank Vesna Horvat, Jocelyne Leclerc and Erika Bohrer of the Institute of Veterinary Anatomy, Zurich and the team of the ETH Zurich for technical support. Moreover, we are thankful for having received financial supports from the Foundation Sur-la-Croix, Basel, Switzerland and the Institute of Veterinary Anatomy Zurich (Director A. Boos).

\section{References}

[1] Vermunt, V. (2004) Herd Lameness-A Review. Major Causal Factors, and Guidelines for Prevention and Control. Proceedings of the 13th International Symposium and 5th Conference on Lameness in Ruminants, Maribor, 11-15 February 2004, 3-18.

[2] Webster, J. (1999) Personal Communication. 
[3] Logue, D.N., Offer, J.E. and McGovern, R.D. (2004) The Bovine Digital Cushion-How Crucial Is It to Contusions on the Bearing Surface of the Claw of the Cow? The Veterinary Journal, 167, 220-221. http://dx.doi.org/10.1016/j.tvjl.2004.02.004

[4] Mülling, C. (2004) Verbesserung durch das Management von Klauenkrankheiten. In: Eise, M. and Landmann, D., Eds., Internationaler Trendreport, Klauengesundheit, Deutsche Landwirtschafts-Gesellschaft e.V., Frankfurt am Main, 151162.

[5] Offer, J.E., Fisher, G.E.J., Kempson, S.A. and Logue, D.N. (2001) The Effect of Feeding Grass Silage in Early Pregnancy on Claw Health during First Lactation. The Veterinary Journal, 161, 186-193. http://dx.doi.org/10.1053/tvjl.2000.0515

[6] Räber, M., Scheeder, M.L.R., Ossent, P., Lischer, C.J. and Geyer, H. (2006) The Content and Composition of Lipids in the Digital Cushion of the Bovine claw with Respect to Age and Location-A Preliminary Report. The Veterinary Journal, 172, 173-177. http://dx.doi.org/10.1016/j.tvjl.2005.03.009

[7] Baird, L.G., Dawson, L.E.R., Young, I.S. and O’Connell, N.E. (2010) Lipid Content and Fatty Acid Composition of the Digital Cushion of Bull offered Different Amounts of Linseed. Journal of Animal Science, 88, 2403-2409. http://dx.doi.org/10.2527/jas.2009-1972

[8] Geyer, H. et al. (2015) Anatomie der Rinderklaue. In: Lischer, C.J., et al., Eds., Klauenpflege (Handbuch zur Klauenpflege beim Rind), 4th Edition, Landwirtschaftliche Lehrmittelzentrale, Zollikofen, 13-31.

[9] Geyer, H. (2015) Das Zehenendorgan. In: Salomon, F.-V., Geyer, H. and Gille, U., Eds., Anatomie für die Tiermedizin, 3rd Edition, Enke Verlag, Stuttgart, 659-679.

[10] Izci, C., Erol, M. and Göksahin, E. (2011) A Study about Determing the Changes in the Structural Characteristics of the Digital Cushion in Heifer and Multipar Dairy Cows: A Preliminary Report. Kafkas Universitesi Veteriner Fakultesi Dergisi, 17, 159-162.

[11] Mülling, C. and Hagen, J. (2012) Bedeutung von Klauenerkrankungen und Funktionelle Anatomie der Klaue. Der Praktische Tierarzt, 93, 4-9.

[12] Casutt, M.M., Scheeder, M.R.L., Escher, F., Dufey, P.-A. and Kreuzer, M. (1999) Relating Texture Properties and Composition of Bovine Fat Tissue. Lipid-Fett, 101, 283-290. http://dx.doi.org/10.1002/(SICI)1521-4133(199908)101:8<283::AID-LIPI283>3.0.CO;2-O

[13] Greenough, P.R., Weaver, A.D., Broom, D.M., Esslemont, R.J. and Galindo, F.A. (1997) Basic Concepts of Bovine Lameness. In: Greenough, P.R. and Weaver, A.D., Eds., Lameness in Cattle, John Right and Sons Ltd., Bristol, 5-12.

[14] Letter, V. (2007) Influence of the Feeding on the Fat Pads in the Bovine Digital Cushion. Thesis, Vetsuisse-Faculty, University of Zurich, Zürich.

[15] Ossent, P. and Lischer, C.J. (1997) Post Mortem Examination of the Hooves of Cattle, Horses, Pigs and Small Ruminants under Practice Conditions. In Practice, 19, 21-29. http://dx.doi.org/10.1136/inpract.19.1.21

[16] van der Tol, P.P.J., Metz, J.H.M., Noordhuizen-Stassen, E.N., Back, W., Braam, C.R. and Weijs, W.A. (2002) The Pressure Distribution under the Bovine Claw during Square Standing on a Flat Substrate. Journal of Dairy Science, 85, 1476-1481. http://dx.doi.org/10.3168/jds.S0022-0302(02)74216-1

[17] van der Tol, P.P.J., Metz, J.H.M., Noordhuizen-Stassen, E.N., Back, W., Braam, C.R. and Weijs, W.A. (2003) The Vertical Ground Reaction Force and the Pressure Distribution on the Claws of Dairy Cows while Walking on a Flat Substrate. Journal of Dairy Science, 86, 2875-2883. http://dx.doi.org/10.3168/jds.S0022-0302(03)73884-3

[18] van der Tol, P.P.J., Metz, J.H.M., Noordhuizen-Stassen, E.N., Back, W., Braam, C.R. and Weijs, W.A. (2004) The Force and Pressure Distribution on the Claws of Cattle and the Biomechanical Effect of Preventive Trimming. Proceedings of the 13th International Symposium and 5th Conference on Lameness in Ruminants, Maribor, 11-15 February 2004, 62-64.

[19] Sambraus, H.H. (1994) Atlas der Nutztierrassen. Verlag Eugen Ulmer, Stuttgart, 248.

[20] Lean, I.J., Westwood, C.T., Golder, H.M. and Vermunt, J.J. (2013) Impact of Nutrition on Lameness and Claw Health in Cattle. Review Article. Livestock Science, 156, 71-87. http://dx.doi.org/10.1016/j.livsci.2013.06.006

[21] Bicalho, R.C., Machado, V.S. and Caixeta, L.S. (2009) Lameness in Dairy Cattle. A Debilitating Disease or a Disease of Debilitated Cattle? A Cross-Sectional Study of Lameness Prevalence and Thickness of the Digital Cushion. Journal of Dairy Science, 92, 3175-3184. http://dx.doi.org/10.3168/jds.2008-1827

[22] Tarlton, J.F., Holah, D.E., Evans, K.M., Jones, S., Pearson, G.R. and Webster, A.J.F. (2002) Biomechanical and Histopathological Changes in the Support Structures of Bovine Hooves around the Time of First Calving. The Veterinary Journal, 163, 196-204. http://dx.doi.org/10.1053/tvjl.2001.0651

[23] Wood, J.D. and Enser, M. (1997) Factors Influencing Fatty Acids in Meat and the Role of Antioxidants in Improving Meat Quality. British journal of Nutrition, 78, 49-60. http://dx.doi.org/10.1079/BJN19970134 
[24] Kouba, M., Enser, M., Whittington, F.M., Nute, G.R. and Wood, J.D. (2003) Effect of a High-Linolenic Acid Diet on Lipogenic Enzyme Activities, Fatty Acid Composition and Meat Quality in the Growing Pig. Journal of Animal Science, 81, 1967-1979.

[25] Lefaucheur, L., Le Dividich, J., Mourot, J., Monin, G., Ecolan, P. and Krauss, D. (1991) Influence of Environmental Temperature on Growth, Muscle and Adipose Tissue Metabolism, and Meat Quality in Swine. Journal of Animal Science, 69, 2844-2854. 